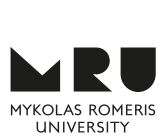

\title{
ŽMOGIŠKOJO KAPITALO KONCEPTUALIZACIJA: RAIDA, SAMPRATA IR FORMAVIMAS
}

\author{
Simona POTELIENÉ \\ Šiaulių universitetas, Socialinių mokslų fakultetas \\ Architektų g. 1, LT-78366 Šiauliai, Lietuva \\ Elektroninis paštas: simona.ind@gmail.com

\section{Zita TAMAŠAUSKIENE்} \\ Šiaulių universitetas, Socialinių mokslų fakultetas \\ Architektų g. 1, LT-78366 Šiauliai, Lietuva \\ Elektroninis paštas: zita.tamasauskiene@smf.su.lt
}

doi:10.13165/VSE-14-4-1-08

Santrauka. Nors žmogiškojo kapitalo koncepcija ypatingo mokslininkų dèmesio sulaukè per pastaruosius penkis dešimtmečius, idejos apie žmogiškajj kapitalą ir žmogiškojo kapitalo sąvoką bei tai, kad ịgyti gebèjimai ir ịgūdžiai - tai kapitalas, investavimo ị žmones būtinybè siekiant didinti produktyvumą, buvo gvildenamos jau gerokai anksčiau. Straipsnyje atskleidžiamos žmogiškojo kapitalo teorijos ištakos, siekiančios XVII-XIX a., pateikiama žmogiškojo kapitalo ekonominès minties istorinė raida, gvildenami žmogiškojo kapitalo sampratos diskusiniai klausimai, apibrèžiami pagrindiniai žmogiškąji kapitalą sudarantys elementai bei aptariami veiksniai, turintys ịtakos žmogiškojo kapitalo formavimui.

Reikšminiai žodžiai: žmogiškasis kapitalas, žmogiškojo kapitalo ekonominès minties istorinè raida, žmogiškojo kapitalo formavimas.

JEL klasifikacija: E24, J24.

\section{Ivadas}

Visuotinai priimta, kad ekonomikos augimą lemia trys gamybos veiksniai - žemé, darbas ir kapitalas, prie kurių taip pat priskiriamas ir verslumas (Nafukho et al., 2004; Mincer, 1962, Becker, 1993a, Siddiqui, 1996). Darbas apibūdinamas kaip visi gamybos procesams naudojami žmogiškieji visuomenès ištekliai (Pass et al., 1997) ar, kaip nurodyta ekokonomikos terminų žodyne, žmogaus fizinių bei protinių gebejjimų naudojimas prekių ar paslaugų gamyboje. Nors žmogiškojo kapitalo koncepcija mokslininkų dèmesio ypač sulaukẻ per pastaruosius penkis dešimtmečius, idejos apie žmogiškąji kapitalą ir žmogiškojo kapitalo sąvoką bei tai, kad igyti gebejjimai ir igūdžiai - tai kapitalas ar investavimo ị žmones 
būtinybė siekiant didinti produktyvumą, buvo gvildenamos jau žymiai anksčiau. Jos ištakos siekia XVII-XIX a. Iš pradžių iš dirbančiųjų buvo tikètasi tik fizinio darbo, nesureikšminant jų asmeninių gebejjimų. Tačiau jau XVIII a. A. Smith’ui plètojant mintį, kad dirbantys žmonès nèra vien tik masė, bet greičiau individai, turintys vertingų gebejjimų (Keeley, 2007), remiantis skirtingu asmens žmogiškojo kapitalo lygiu buvo bandoma paaiškinti skirtingų darbuotojų gaunamą skirtingo dydžio darbo užmokestį. Tačiau ị tai, kad individualūs gebejimai yra tam tikra kapitalo rūšis, plačiau imta gilintis vèliau, t. y. tik septintajame dešimtmetyje, daugiau domintis augančia ekonomika, jos dinamika, pajamų diferenciacija, kas skatino labiau plètoti žmogiškojo kapitalo teoriją, tapusią viena iš pamatinių socialinès ir ekonominès plètros teorijų (Abeltina, 2008, Kuliešis et al., 2012).

Šiuolaikinis terminas „žmogiškasis kapitalas“ pirmą kartą pavartotas 1960-1970 m. J. Mincerio (1958), R. B. Goode’o (1959), T. W. Schultzo (1961) ir G. S. Beckerio (1962, 1964, 1975) atskleidžiant kitoki požiūrị ị žmogiškojo kapitalo sampratą ir jo formavimą. Dabar visuotinai sutariama ir laikomasi nuomonès, kad aukštesnio lygio žmogiškasis kapitalas skatina spartesnius ekonominio augimo tempus. Itvairiais tyrimais įrodyta, kad žmogiškasis kapitalas yra pagrindinis įvairių šalių pajamų ir gerovès svyravimo šaltinis.

Atsižvelgiant ị plačias diskusijas apie žmogiškojo kapitalo vaidmenị ir jo ịtaką nustatant asmens pajamas ir ekonomikos augimą, aktualu atskleisti žmogiškojo kapitalo sampratą ekonominès minties istorinès raidos kontekste. Straipsnio tikslas - išanalizavus žmogiškojo kapitalo ekonominès minties istorinę raidą bei žmogiškojo kapitalo sampratos diskusinius klausimus, ̨̣vardinti pagrindines žmogiškojo kapitalo sudedamąsias dalis bei veiksnius, turinčius įtakos žmogiškojo kapitalo formavimuisi, pateikiant jų charakteristikas.

Tyrimo objektas - žmogiškasis kapitalas.

Tyrimo metodai - sisteminè mokslinès literatūros analizè, apibendrinimas.

\section{Žmogiškojo kapitalo ekonominès minties istorinė raida}

Šiuolaikinis terminas „Žmogiškasis kapitalas“ pirmą kartą paavartotas 1960-70 m., J. Mincerio (1958), R. B. Goode’o (1959), T. W. Schultzo (1961) ir G. S. Beckerio (1962, 1964, 1975) atskleidžiant kitoki požiūrị i žmogiškojo kapitalo sampratą ir jo formavimą. Žmogiškojo kapitalo kaupimas iggavo svarbią reikšmę nagrinėjant pajamų diferenciaciją bei atsiradus endogeninio augimo teorijoms. Endogeninė augimo (Lucas, 1988) ir papildyta Solow augimo (Romer, 1989, 1990, Mankiw et al., 1992) teorijos pabrěžia žmogiškojo kapitalo svarbą nustatant darnųj ̨ ekonomikos augimą. Laikomasi nuomonès, kad aukštesnio lygio žmogiškasis kapitalas skatina spartesnius ekonominio augimo tempus. Ivairiais tyrimais įrodyta, kad žmogiškasis kapitalas yra pagrindinis tokio ịvairių šalių pajamų ir gerovès svyravimo šaltinis. Remiantis šia teorija galima pagrịsti darbo užmokesčio diferenciaciją pagal profesiją, amžių, išteklių paskirstymą švietimui ir pan.

Nors žmogiškojo kapitalo koncepcija ypatingo mokslininkų dėmesio sulaukè per pastaruosius penkis dešimtmečius, idejos apie žmogiškajj kapitalą ir žmogiškojo kapitalo sąvoką bei tai, kad igyti gebejimai ir igūdžiai - tai kapitalas ar investavimo ị žmones būtinybė, siekiant didinti produktyvumą, daugelio mokslininkų manymu (Folloni ir Vittadini, 2010, Lovaglio ir Folloni, 2011, Verhoglyadova, 2006, Weisbrod, 1966, Turunen, 2007 ir kt.), buvo gvildenamos jau žymiai anksčiau. Jos ištakos siekia XVII-XIX a.

Žmogiškojo kapitalo teorijos kilmè: ankstyvoji žmogiškojo kapitalo teorija. Daugiau nei prieš du-tris šimtmečius ekonomistai teoretikai jau domejjosi žmogaus darbo jègos ga- 
lios (darbingumo, gebėjimų) kūrimu, kaupimu bei panaudojimu. A. Hofflanderis (1966) nurodo, kad daug filosofų ir ekonomistų yra prisidèję prie žmogiškojo kapitalo koncepcijos vystymo, kartu pažymėdamas, kad šiek tiek panaši ị dabartinę žmogiškojo kapitalo koncepciją idèja egzistavo jau senojoje anglosaksų teisèje - ja vadovautasi nustatant nužudytojo artimiesiems kompensacijos dydị, kai asmuo būdavo nužudytas trečiosios šalies.

Pirmuoju ekonomistu, pripažinusiu žmogaus ekonominę vertę, yra laikomas Seras W. Petty (1623-1687) (Folloni ir Vittadini, 2010, Hofflander, 1966, Kiker, 1966, Lovaglio ir Folloni, 2011). Pats žinomiausias Ekonomikos politinès aritmetikos mokyklos (Political Arithmetic School of Economics) ịkūrejas ir taikomosios ekonometrikos pirmtakas W. Petty domejjosi pagrindinėmis žmogiškojo kapitalo socialinėmis, ekonomimėmis ir politinėmis funkcijomis (Folloni ir Vittadini, 2010). Jis tikèjo, kad darbas yra „gerovès tèvas", ir siūlè ji būtinai įtraukti matuojant nacionalinę gerovę (Folloni ir Vittadini, 2010). W. Petty studijos buvo sutelktos ị žmogiškojo kapitalo pinigini ịvertinimą ir emigracijos įtaką ekonomikai. Jo tyrimų tikslas buvo parodyti, kad ir kiti veiksniai, be ploto (teritorijos) ir gyventojų skaičiaus, yra svarbūs nustatant tautos turtus (gerovę) ir jègą (stiprumą). Remdamasis statistiniais duomenimis jis bande parodyti, kad Anglija, nors jos teritorija ir maža, turèdama gamtinių privalumų (pvz., aukštos kokybès ir nebrangią laivybos infrastruktūrą) gali tapti didžiausia šalimi. W. Petty buvo įsitikinęs, kad, siekiant ịvertinti Anglijos nacionalinį turtą, pirmiausia reikia nustatyti gyventojų vertę (Hofflander, 1966).

Kitas ekonomistas (tik maždaug po 50 metų), įnešęs savo indèlị ị žmogiškojo kapitalo sąvokos formavimą, buvo $\mathrm{Ph}$. Cantillonas (1680-1734). Jo vertinimas buvo grindžiamas vergo ir jo palikuonių išlaikymo išlaidų lyginimu su jo sukurtomis pajamomis. Tai tiesiogiai prieštaravo W. Petty, kuris kapitalizavo darbo pajamas. Ph. Cantillonas labiau domėjosi individualaus ūkio ar plantacijos vergų vertinimu, priešingai nei W. Petty, kuris akcentavo bendronacionalinio turto matavimą (Hofflander, 1966).

Skirtingai nei pirmtakai, A. Smithas (1723-1790) neskyrè daug dèmesio žmogiškojo kapitalo vertės nustatymui, o domėjosi darbo užmokesčio skirtumais ịvairiose srityse bei bandè paaiškinti šiuos skirtumus žmogiškojo kapitalo koncepcijos požiūriu. A. Hofflanderio (1966) teigimu, A. Smithas šį klausimą nagrinèjo tik du kartus savo veikale „Tautų turtas“ (Wealth of Nations). Pirmoji nuoroda ị darbo užmokesčio ir pelno skirtumus buvo jo pateikta mintis, kad išsimokslinęs žmogus gali būti prilygintas brangioms mašinoms (pagrindiniam kapitalui), pažymint, kad jo pajamos turètu apimti ne tik ịprastą nekvalifikuoto darbo atlygí, bet taip pat padengti ir išsilavinimo išlaidas. Iš šių teiginių atrodo, kad A. Smith’as žmogų laike žmogiškuoju kapitalu, tačiau kitame skyriuje, kuriame išvardijo pagrindinio kapitalo sudedamąsias dalis, jis ịvardijo ne žmogų, o veikiau ,ịsigytus ir naudingus visų gyventojų ar visuomenès narių gebėjimus" (Hofflander, 1966 p. 383, citavo A. Smith, 1937, p. 101).

J. M. Corona Alcantaras (2006), M. Laroche ir bendraautorių (1999) teigimu, A. Smithas buvo pirmasis asmens igūdžius, gebẻjimus ir žinias ịvardijęs kaip žmonių svarbias savybes, vertinant jų ekonominę veiklą. Svarbus A. Smitho indèlis ị žmogiškojo kapitalo teoriją buvo išsilavinimo ir darbo metu asmens igytų žinių bei igūdžių ekonominès vertès nustatymas. Jis nurodè, kad iggti igūdžiai, gebẻjimai ir sprendimai, taikomi darbe, yra lemiamas produktyvumo augimo ir gerovès kūrimo veiksnys (Sweetland, 1996). Jis pirmasis ịžvelgè, kad žmonių žinios ir ịūdžiai yra glaudžiai susiję su inovacijomis, technologiniais pokyčiais ir ekonominès veiklos rezultatais (Corona Alcantar, 2006) bei tai, kad žmoniu gebẻjimai didina visuomenès ir individo gerovę (Laroche et al., 1999). A. Smithas (1776/2009, p. 166) rašè: 
„Tokiu talentu igijimas žmogaus pastangomis besimokant, studijuojant ar atliekant praktika visuomet reikalauja realiu išlaidų, kurios tampa kapitalu, saugomu ir realizuojamu pačiame žmoguje. Šie talentai prisideda prie žmogaus sèkmès, taip pat padeda visuomenei, kuriai šis žmogus priklauso. I patobulintus darbuotojo igūdžius galima žiūrèti lygiai taip pat, kaip i pramoninę mašina ar ịrenginį, kuris palengvina ir trumpina darbo procesą, ir nors reikalauja tam tikru išlaidu, atsiperka su kaupu. “

J. H. von Thünenas (1783-1850) taip pat svarstė galimybę žmogų ịvardinti kapitalu. Jis išvedė lygtị, kuria buvo galima išmatuoti žmogaus gyvenimo vertę (lygtis buvo paskelbta po jo mirties). Tačiau, A. Hofflanderio (1966) teigimu, pradinè naudota formulè nerodè pagrịstų verčių pakeitimų, o ir pačios lygties taikymas nedavè reikšmingų rezultatų. Von Thünenas laikèsi nuostatos, jei vyras būtų prilygintas kapitalui, tai reikètų: (1) kompensuoti kiekvieno žuvusio kareivio šeimai jo ugdymo išlaidas, (2) karo invalidams padengti jų ugdymo išlaidas ir mokèti už jų priežiūrą ir išlaikymą bei (3) sugrị̌žusiems sveikiems kareiviams padengti išlaidas, susijusias su jų pareikalautos sveikatos išeikvojimu.

J. St. Mill’as (1806-1873) daugiau žinomas kaip žmogiškojo kapitalo teorijos kritikas. Jis teigè, kad šalies žmonių klasifikavimas negali tinkamai įvertinti jos turto. Vèliau J. St. Mill'as, panašiu būdu kaip ir A. Smith'as, bandè atskirti darbuotojo igūdžius nuo asmenybės. Jis prie turto priskyrė darbuotojo igūdžius, bet ne jo asmenybę (Hoflander, 1966).

Tuo tarpu W. Farr'as (1807-1883) iš esmès grịžo prie W. Petty taikyto metodo, tačiau jo požiūris buvo žymiai sudètingesnis. W. Farr'as teigè, kad gyventojai negali būti vertinami kaip visuma, - jie turètų būti suskirstyti ị mažas homogenines grupes. Jis bandè rasti teisingą gyventojų apmokestinimo sistemą ir manè, kad kiekvienas bendruomenès narys turi kasmet prisidèti prie valstybės išlaidų dengimo proporcingai nustatyta suma nuo jo turimo turto per ataskaitinius metus. W. Farr'as pateike asmens turto vertés nustatymo metodą (arba žmogaus gyvenimo vertės metodą), pagrịstą pridètinès vertės sąvoka, teigdamas, kad asmens būsimų pajamų dabartinè vertè, atemus būtinuosius kaštus šioms pajamoms uždirbti, yra asmens paslaugų dabartinè vertė (Hoflander, 1966; Kiker, 1966, Le et al., 2005). 1853 m. W.Farr'as pasiūlè, kad asmens dabartinẻ būsimų grynųjų pajamų vertė, kurias apibrèžè kaip pajamas atskaičius pragyvenimo išlaidas, rodančias gerovę (turtą), turètų būti apmokestinama panašiai kaip ir fizinis kapitalas. T. Wittsteinas 1867 m. pasiūlè, kad W. Farro aptarta dabartinè būsimų grynụjų pajamų vertẻ būtų naudojama nustatant kompensacijas vertinant žmogaus (gyvybès) netektis (Kiker, 1966). S. Hubneris (1882-1964), Amerikos gyvybės draudimo koledžo prie Pensilvanijos universiteto ịkūrèjas, $1914 \mathrm{~m}$. laikèsi nuomonès, kad žmogaus gyvybės kaina (vertè) turètų būti nustatoma tokiu pačiu moksliniu būdu, koks yra taikomas ịprastiniam kapitalui (Kiker, 1966).

A. Marshall'o (1842-1924) taikytas metodas buvo beveik identiškas W. Farr’o taikytam metodui, išskyrus tai, kad asmens pajamos ir išlaikymo išlaidos buvo laikomos tolydžiuoju, o ne diskrečiuoju kintamuoju, kaip W. Farro modelyje (Hoflander, 1966). Vèliau, po 80 metų (1930 m.), A. Marshall'o metodą patobulino L. I. Dublinas ir A. Lotka (Folloni ir Vittadini, 2010, Le et al., 2005).

Daugelis kitų ankstyvụjų autorių žmogiškojo kapitalo ekonomikos literatūroje ịvairiais būdais teigè, kad žmonès yra investicija, kuri generuoja grąžą. Tarp jų B. F. Kikeris (1966) yra išskyręs A. Smith'ą (1776), J. B. Say (1821), J. St. Millą (1909), W. Roscherą (1878) ir H. Sidgwickị (1901). Žmonès buvo ịtraukti ir ị I. Fisherio (1867-1947) kapitalo apibrèžimą 1897 m. Daugelis kitų ankstyvųjų mokslininkų pripažino šią sąvoką, bet atsisakè vertinti žmones tokiu pačiu principu kaip ir fizines prekes (Kiker, 1966). 
XIXa. pabaigoje - XX a. pradžioje susiformavo dvi ekonominės minties kryptys, analizuojančios sąvoką „žmogiškasis kapitalas“. Kaip jau minèta, A. Smith’as igūdžius ir gebejjimus buvo ịtraukęs ị pagrindinị kapitalą. Beveik tokios pačios nuomonès laikèsi ir kiti autoriai (F. List, J. B. Say, J. St. Mill, W. Rosher, W. Bagehot, N. Senior, H. Sidwick, F. List, G. Z. Walsh) teigdami, kad igūdžiai ir gebejjimai yra igyjami patiriant sąnaudas, kurios paprastai didina darbuotojo produktyvumą. Tačiau jie konkrečiai ir aiškiai neịvardijo žmonių kaip kapitalo (Turunen, 2007) ir laikèsi nuostatos, kad kapitalas priklauso nuo žmogaus savybių ir gebejjiтų (Дятлов, 1994). J. St. Mill’o žodžiais, „Pats individas ... nèra kapitalas. Žmogus yra gerovés pasiekimo ịrankis. Bet jo turimi gebẻjimai, kurie išreiškiami ir vertinami tik kaip darbo metodai, be jokiu abejoniu, gali būti laikomi viena iš kapitalo kategorijų“ (Корицкий, 2007, p. 4).

Kitos krypties šalininkai žmogų vertino kaip kapitalą (tarp jų paminėtini: L. Valras, G. M. Clark, H. D. McLeod, T. Witshtane, W. Farr, I. Fisher, N. W. Senior, H. D. McCleod, J. H. von Thünen, J. R. McCulloch, A. Marshal) (Turunen, 2007, Дятлов, 1994). Kaip teigia B. F. Kikeris (1966), nors jie žmones ar jų igytus igūdžius ir gebejjimus ịtraukè ị savo kapitalo koncepciją ir investavimą i žmones matẻ kaip produktyvumo didinimo galimybę, jie šios koncepcijos nenaudojo jokiam konkrečiam tikslui ir nè nebande įvertinti žmogiškujų išteklių atsargų (žmogiškojo kapitalo) kiekybiniu požiūriu.

Šiuolaikine žmogiškojo kapitalo teorija. Nors žmogiškojo kapitalo teorijos užuomazgos buvo plètotos W. Petty, A. Smith’o, A. Marshall'o, I. Fisherio ir kitų mokslininkų darbuose, žmogiškojo kapitalo koncepcija ekonomistų buvo ilgą laiką primiršta iki jos atgimimo septintojo dešimtmečio pradžioje, kai pasirode T. W. Schultzo $(1961,1962)$, pripažinto šios idejos autoriumi, G. S. Beckerio $(1962,1964)$ ir J. Mincerio $(1958,1962,1974)$, suformulavusių šią teoriją remiantis savo tyrimais ir ankstesnèmis iškilių ekonomistų - A. Smitho, I. Fisherio ir F. Knighto ir kt. - idejomis, darbai. Šie ekonomistai priminè šią senąją koncepciją, dar kartą patvirtindami jos sąryšį su ekonominiu augimu ir pabréždami jos svarbą aiškinant darbo užmokesčio skirtumus.

Tuo pačiu laikotarpiu, kuriant neoklasikinę (Solow ir Swano) augimo teoriją, nepavyko pateikti mechanizmo, kaip ịtraukti žmogiškąji kapitalą kaip augimo variklį. Neoklasikiniuose augimo modeliuose (pristatytuose tokių ekonomistų kaip R. M. Solow ir T. W. Swanas 1956 m.) kapitalo ir darbo jejgos kiekis buvo laikomas ekonomikos augimą lemiančiais veiksniais. Tačiau tokie veiksniai kaip žmogiškojo kapitalo kokybè ar darbuotojų sveikata šiuose modeliuose buvo visiškai ignoruojami (Akbari et al., 2012 cit. Hers, 1998). Toks mechanizmas tapo galimas vèliau, pasirodžius novatoriškam P. Romero (1986) ir R. E. Luco (1988) darbui ir naujai endogeninio augimo teorijai, kuri sužadino ekonomistų domèjimąsi žmogiškojo kapitalo, kaip ekonominio augimo veiksnio, vaidmeniu. Pagal kai kuriuos iš šių modelių, žmogiškasis kapitalas stimuliuoja augimą, skatindamas technologinę pažangą arba didindamas darbo produktyvumą (Laroche et al., 1999). Pastarųjų metų ekonominio augimo empiriniai tyrimai taip pat rodo, kad šalies gyventojų gebejimai ir žinios yra svarbūs, nustatant jos ekonominę veiklą. Pavyzdžiui, esant didesniems žmogiškojo kapitalo ištekliams, mažiau išsivysčiusi šalis dèl spartesnio tarptautinių technologijų arba imitacinių galimybių panaudojimo gali greičiau priartèti prie išsivysčiusios šalies pajamų lygio.

Kaip teigè pirmasis pavartojęs žmogiškojo kapitalo sąvoką moderniojoje ekonomikos literatūroje T. W. Schultzas (1998), visuomenės gerovę pirmiausia lemia investicijos ị žmones. Jis tvirtino, kad lemiantys veiksniai, leidžiantys padidinti neturtingų šalių gerovę, yra ne tiek žemė ar pasèlių plotai, bet gyventojų kokybės gerinimas, investuojant daugiau i išmokslinimą bei ị sveikatos apsaugą. Jis pabrèžè, kad žmonių igyjamos vertybès - jų išsilavinimas, patirtis, ł̇gūžiai, sveikata - yra svarbiausios siekiant ekonominès pažangos. 
Išlaidas žmogiškajam kapitalui įsigyti T. W. Schultzas traktavo ne kaip vartojimo išlaidas, o priskyrè prie investicijų. Jo nuomone, žmogiškuoju kapitalu vadinami „požymiai igytos gyventojų kokybès, kuri yra vertinga ir kuri gali būti padidinama atitinkamai investuojant" (Chlivickas ir Papšienè, 2009b, p. 37).

T. W. Schultzas straipsnyje „Investavimas ì žmones“ (Investment in human capital, 1961) teigè, kad žinios ir igūdžiai yra kapitalo rūšis, ir kad šis kapitalas yra vienas iš labiausiai apgalvotų kapitalo formos investicijų. T. W. Schultzas pabrèžè, kad Vakarų šalyse labai išaugo nacionalinè produkcija padidejus investicijoms į žmogiškąji kapitalą, taip pat nustatė tiesioginị ryšị tarp investicijų i žmogiškąji kapitalą ir bendro darbuotojų darbo užmokesčio padidejjimo. Jis laikèsi nuomonès, kad absoliutūs nekvalifikuotų darbininkų ir išsimokslinusių darbuotojų uždarbių skirtumai rodo investavimo ị žmogiškąji kapitalą grąžą, ir padare išvadą, kad „pajamos, gaunamos investuojant i išsilavinima, yra patrauklesnès nei investuojant i fizinị kapitala" (Bagdanavičius, 2002, p. 80).

Kitas svarbus indèlis formuojant modernią žmogiškojo kapitalo teoriją yra G. S. Beckerio darbai, kuriuose, plètodamas ankstesnius teiginius, jis sukūrè žmogiškojo kapitalo požiūrị i bendrąją teoriją, nustatant darbo pajamų pasiskirstymą. Atsižvelgdamas ị darbo užmokesčio struktūrą, jis suformulavo žmogiškojo kapitalo ir darbo užmokesčio funkcijas, nurodančias ryšị tarp žmogiškojo kapitalo ir pajamų. Šis indèlis pirmą kartą buvo pristatytas 1960-ųjų pradžioje keliuose straipsniuose ir vèliau teoriškai ir empiriškai išplètotas jo knygoje apie žmogiškaji kapitalą 1964 m. (Becker, 1992; Press Release,1992).

G. S. Beckerio teorinis darbas, kuris paskatino investicijų grąžos tarp skirtingų darbo jègos pogrupių îvertinimą (pavyzdžiui, pogrupiai pagal lytị ir rasę) skirtingais laikotarpiais ir skirtingose šalyse, skirtinguose švietimo sistemos lygiuose (pavyzdžiui, vidurinès mokyklos baigimas, pirmi du metai koledže, koledžo baigimas) ir skirtinguose mokymų ir švietimo sistemų tipuose, suteikè išsilavinimo lygio normų skirtumų prognozavimo pagrindus tarp pogrupių, šalių, švietimo lygmenų ir mokymų tipų (Coleman, 1993, p. 171).

G. S. Beckeris (1962) nustatė investavimo ị žmogiškąj kapitalą poveikį uždarbių dydžiui ir pasiskirstymui apskaičiuodamas veiklos, kuri turi įtakos būsimoms realioms pajamoms dẻl „išteklių, glüdinčių žmonèse“, vertę (p. 9). Tokia veikla apima išsilavinimą, apmokymus darbo vietoje, sveikatos priežiūrą ir informaciją apie rinką (kurią jis priskyrè prie „kitų žinių“).

Kitas mokslininkas, taip pat kaip ir G. S. Beckeris, akcentavęs ir nagrinėjęs žmogiškąji kapitalą mikropožiūriu (T. W. Schultzas išsilavinimą ir žmogiškajji kapitalą nagrinèjo platesne prasme) - J. Minceris, kaip ir dauguma tuometinių mokslininkų, kartu analizavo skirtumus tarp amžiaus ir darbo patirties, išsilavinimo lygio bei kokią ịtaką jie turi darbo užmokesčiui. Jis pirmasis apskaičiavo išsilavinimo ir tolesnio kvalifikacijos kèlimo atsipirkimą, ištyrè moters vaidmenị uždirbant šeimos pajamas, sukūrè teorinị modelį, parodantị papildomų vienerių metų studijų / mokymosi įtaką individo pajamoms, kuris, kaip teigia E. D. Bloomas ir A. Siow (1993), skirtingai nei dauguma kitų to meto ekonomistų analitinių tyrimo metodų, praejjus daugiau nei 40 metų, yra taikomas iki šiol. J. Mincerio modelis matavo dviejų tipų mokymą, neformalų ir formalų, įtraukiant mokymosi ir darbo patirties metų skaičių. Jo tyrimų rezultatai parodè, kad didesnis metų skaičius, skirtas mokymuisi, buvo kompensuotas didesniu darbo užmokesčiu (Turunen, 2007).

Šiuolaikinès darbo ekonomikos tèvo (Jacob Mincer's Biography) J. Mincerio teigimu (1981), žmogiškasis kapitalas apima ne tik žinių perdavimą ar turimų igūdžių didinimą, bet ir naujos produkcijos atsiradimą, kuri skatina inovacinę ir techninę ekonomikos plètrą, gamybos gerinimą. Todèl, jo nuomone (1981), žmogiškasis kapitalas skatina pasaulio eko- 
nomikos augimą, o ekonomikos demografiniai pokyčiai yra veikiami žmogiškojo kapitalo (Mincer, 1981, p. 1).

Kaip konstatuoja E. D. Bloomas ir A. Siow (1993), 1960-1970 m. J. Minceris ir G. S. Beckeris, būdami kolegos Kolumbijos universitete, inicijavo ir išvyste tyrimus darbo tema, kuriuos peremė dabartiné moderni ekonomika ir taip buvo pagaliau ,išaugta“ iš „pasenusių" ir nusistovejusių nuostatų.

Taigi, žmogiškasis kapitalas šių dienų modernioje ekonomikos teorijoje yra toks ịprastas ir nekontroversiškas reiškinys, kad, kaip teigia vienas iš šios teorijos pradininkų, Nobelio premijos laureatas G. S. Beckeris (1993b): „šiais laikais <...> sunku suvokti tą priešiškumą, kurio jis (žmogiškasis kapitalas) susilauke šeštajame ir septintajame dešimtmetyje “ (p. 392). Anksčiau buvo teigiama, kad žmogiškojo kapitalo sąvoka yra žeminanti, nes žmonès sulyginami su mašinomis ir ịrenginiais. Sutapatinti mokymąsi su investicijomis į žmogų buvo sudètinga, nes žmoniu požiưris buvo gana siauras (Becker, 1993b). Tik palaipsniui ekonomistai pripažino ir prièmé žmogiškojo kapitalo koncepciją kaip vertingą ir neįkainojamą priemonę analizuojant ịvairius ekonominius ir socialinius reiškinius. Nuo to laiko žmogiškasis kapitalas tapo viena pagrindinių socioekonominés plètros teorijų ir susilauké vis daugiau dèmesio naujoje žinių ekonomikos eroje, kai žiniomis paremtų technologijų projektavimas ir naudojimas tapo kasdienybe (Verhoglyadova, 2006).

Apibendrinant žmogiškojo kapitalo teorijos ištakas, darytina išvada, kad ekonominiu požiūriu žmogus istoriškai buvo pripažintas svarbiausiu veiksniu kuriant tautų gerovę. Pavyzdžiui, klasikinès ir neoklasikinès mokyklos žmones laikè svarbiu faktoriumi dèl jų fizinių gebëjimų atlikti tam tikras užduotis. Daugelyje klasikinių ir neoklasikinių požiūrių žmonès yra skaičiuojami tik kiekybiniu požiūriu, prilyginant juos „darbo vienetui“ ar „darbo valandoms" gamybos procese. Analitiniu požiūriu žmonès tokiose teorijose traktuojami kaip homogeninis veiksnys (homogeneous agents), kur kiekvienas darbo jegos vienetas yra laikomas identiškas kitam bet kurioje pramonès šakoje, sektoriuje ar regione. Todèl gamybiniai žmogaus pajegumai arba žmonių produktyvumas laikytas neaiškiu ir neapibrèžtu. Laikui bègant ekonomistai išstudijavo žmogaus ịnašą i turto ir geroves kūrimą platesniu požiūriu ir, nepamiršdami jų vaidmens kiekybiniu požiūriu, pabrèže jų kokybinị pobūdị. Ši idejja teige, kad igundžiai, gabumai, išsilavinimas, žinios, informacija, taip pat asmeninių sprendimų ir pažinimo galimybès parodo svarbiausias žmogaus savybes, kurios negali būti ignoruojamos, svarstant žmonių produktyvumą ir naujovių diegimą. Nors kiekvieno asmens šios savybès yra skirtingos, laikomasi nuomonès, kad žmones reikètų laikyti ne „homogeniniais veiksnias“, bet, atvirkščiai, „heterogeniniais“.

Šiuo metu yra visuotinai pripažistama žmogiškojo kapitalo reikšme ir jo reikšminga ịtaka tiek individo, tiek visuomenès požiūriu. Visuotinai sutariama, kad žmonių žinių ir igūdžių ịvairové bei skirtingi jų lygiai yra potencialus ekonomikos augimo ir gerovès kūrimo šaltinis. Tai iš tiesų yra veiksnys, galintis paaiškinti inovacijų diegimo galimybių tarp tautų, pramonès šakų ir regionų skirtumus.

\section{Žmogiškojo kapitalo koncepcija ir jos dedamosios dalys}

Apibendrinant žmogiškojo kapitalo teorijos raidą galima konstatuoti, kad literatūroje pateikiama daugybė žmogiškojo kapitalo sampratos aiškinimų. İvairių sričių mokslininkai siūlo daug apibrěžimų, kaip jie supranta žmogiškąji kapitalą, tačiau dažniausiai žmogiškojo kapitalo apibrežimuose akcentuojamos žinios, igūdžiai, gebẻjimai. Tai gerai atsispindi 
žmogiškojo kapitalo teorijos tėvu ịvardijamo T. W. Schultzo (1961) pateikiamame žmogiškojo kapitalo apibrèžime, kuriame ši sąvoka apibūdinama kaip žinių, igūdžių ir gebejjimų visuma, kuria naudojasi individai. Panašiai žmogiškąji kapitalą apibréžia ir kiti mokslininkai (J. Mincer (1962), L. Edvinsson ir P. Sullivan (1996), J. Roos et al. (1998), T. Steward (1997), T. Stewart (1997), R. G. Lipsey et al. (1999), L. Edvinsson ir M. S. Malone (1999), T. O. Davenport (1999), V. Mathur (1999), G. G. Dess ir J. C. Picken (1999), D. J. Knight (1999), M. E. Van Buren (1999), R. Dzinkowski, (2000), B. E. Lynn (2000), R. Legenzova ir S. Ščetko (2001), N. Bontis (2001), M. Lynn (2002), R. Matiušaitytė ir I. Šarkiūnaitė (2003), A. Sullivan ir S. M. Sheffrin (2003), T. Le et al. (2005), E. Chlivickas ir P. Papšienè (2009a), M. J. Kagochi ir C. M. Jolly (2010) ir kt.). Pavyzdžiui, M. Lynnas'as (2000, 2002) nurodo, kad žmogiškasis kapitalas apima darbuotojų gebejimus ir igūdžius organizacijoje, tuo tarpu N. Bontis (1999) įtraukia dar inovatyvumą, gebejimus, o M. E. Van Burenas (1999) kompetencijas. V. Mathuro (1999) nuomone, žmogiškasis kapitalas yra sukaupti gebejjimai ir talentai. L. Edvinssonas ir M. S. Malone’as (1999) nurodo, kad žmogiškąji kapitalą sudaro asmens (darbuotojų) gebejimų, žinių, igūdžių ir patirties visuma, apimanti žinias, ịgūdžius, inovacijas ir atskirų darbuotojų gebejimus susitvarkyti su gautomis užduotimis, taip pat ir įmonès vertę, kultūrą bei filosofiją. Žmogiškasis kapitalas gali būti apibrèžiamas ir kaip žmonių, gyvenančių tam tikroje visuomeneje, žinių, igūdžių, gebejjimų ir gabumų visuma (Onymunwa ir Achime, 2000). T. O. Davenporto (1999) teigimu, žmogiškasis kapitalas sudarytas iš keturių pagrindinių elementų: gebejjimų (apimančių asmens žinias, ịgūdžius ir talentą), elgsenos (tam tikras veiklos / elgesio, padedančio greičiau pasiekti tikslą, pasirinkimas), pastangų (sąmoningas psichinių ir fizinių išteklių naudojimas siekiant rezultato) ir laiko (laikas, skirtas investicijoms ị žmogiškojo kapitalo didinimą). Gamybos požiūriu žmogiškasis kapitalas yra ịgūdžių ir žinių komplektas, suteikiantis tam tikrų gebejjimų atlikti darbą, kuriant ekonominę vertę (Sullivan ir Sheffrin, 2003).

Kiti (G. Becker (1964), G. Psacharopoulos ir M. Woodhall (1985), M. Woodhall (1995), M. Carnoy (1995), R. Blundell et al. (1999), H. S. Rosen (1999), J. Hartog (1999), D. P. Lepak ir S. A. Snell (1999), M. Parkin (2000), J. Bagdanavičius (2002), R. H. Frank ir B. S. Bemanke (2007), J. Barney (1991, 2011), M. J. Kagochi ir C. M. Jolly (2010) labiau išplečia žmogiškojo kapitalo apibrèžimą ịtraukdami mokymą. Tačiau žmogiškasis kapitalas neapsiriboja vien formaliu švietimu. Jis taip pat apima patirtị, praktinị mokymąsi, kuris vyksta ir darbo vietoje, taip pat netradicines kitas mokymo schemas, sudarančias sąlygas tobulinti turimus igūdžius (Davidsson ir Honig, 2003). G. Beckeris (1964) žmogiškąjị kapitalą suprato kaip „fizines gamybos priemones“ (mašinos, prietaisai ir pan.) ir ịvardijo kaip asmens žinias, igūdžius, sugebejimus, kuriuos jis turi dèl igimtų gebejjimų ir vẻlesnio investavimo ị išsilavinimą, tolesnị mokymąsi ir patirties kaupimą. R. Blundell'as ir bendraautoriai (1999) yra išskyrę tris pagrindinius „žmogiškojo kapitalo“ komponentus - tai gebejjimai (igauti ar igimti); kvalifikacija ir žinios, igytos besimokant, bei igūdžiai, kompetencija ir patirtis, igyta darbo vietoje apmokymo metu. R. H. Frankas ir B. S. Bemanke’as (2007) žmogiškąji kapitalą apibrèžè kaip tokių veiksnių, kaip išsilavinimas, patirtis, tolesnis mokymasis, intelektas, energija, darbo įpročiai, patikimumas ir iniciatyvos, kurie turi įtakos darbuotojo ribinio produkto vertei, visumą (Dae-Bong, 2009). J. Barney $(1991,2011)$ ịtraukia dar sveiką nuovoką, protą, intelektą, ryšius ir individo įžvalgas.

Kai kurie mokslininkai, apibūdindami šią sąvoką, akcentuoja žmonių sveikatos vaidmenị (nes nuo jos būklès dažnai priklauso tokie faktoriai, kaip darbingumas, darbo efektyvumas, konkurencingumas, sugebejjimas prisitaikyti prie besikeičiančių gyvenimo sąlygų, atsparumas 
stresams ir pan. (Bagdanavičius, 2002, p. 18), kiti žmogiškajam kapitalui priskiria motyvaciją, energiją ir pan. Pavyzdžiui, R. M. Nureevas (2010), apibūdindamas žmogiškąji kapitalą, pabrèžia ne tik igimtus ir igytus gebejjimus, bendro pobūdžio ir specializuotas žinias, patirtị, sveikatą bei motyvaciją, leidžiančius padidinti darbo produktyvumą ir gauti didesnes pajamas darbo užmokesčio forma, bet ir aplinkos kultūrą bei sugebejjimą savo žinias, igūdžius, gebejjimus tinkamai ir laiku panaudoti. A. Šileika ir Z. Tamašauskienè (2003) šią sąvoką apibūdina kaip žmogaus žinias, igūdžius, patirtị, motyvaciją, energiją, sveikatą, kurie naudojami gamybos ar paslaugų srityje, siekiant pagaminti produktus ir gauti didesnes pajamas.

De la Fuente ir Ciccone (2002) nurodo, kad „žmogiškasis kapitalas yra plati ir daugialypè sąvoka, apimanti daug skirtingų investicijų tipų i žmones. Sveikata ir mityba yra svarbus aspektas tokių investiciju, ypač besivystančiose šalyse, kur šiais atžvilgiais trūkumai gali labai apriboti gyventoju galimybes užsiimti gamybine veikla. $<\ldots>$ tačiau pagrindinis žmogiškojo kapitalo aspektas yra susijęs su žmonių žiniomis ir igūdžiais, sukauptais mokymosi, kvalifikacijos kèlimo metu bei per patirtį“ (p. 10).

Apibendrinant galima teigti, kad nors mokslininkai vartojo ir vartoja skirtingas žmogiškojo kapitalo sąvokas, tačiau pagrindiniai sąvokos žmogiškasis kapitalas turinio komponentai yra bendri - tai žinios, asmeninès / igimtos savybès, igyti igūdžiai ir sugebejjimai, išsilavinimas, patirtis, kompetencijos, emocinè ir psichinè sveikatos būklè ir pan.

1 pav. Žmogiškojo kapitalo elementai

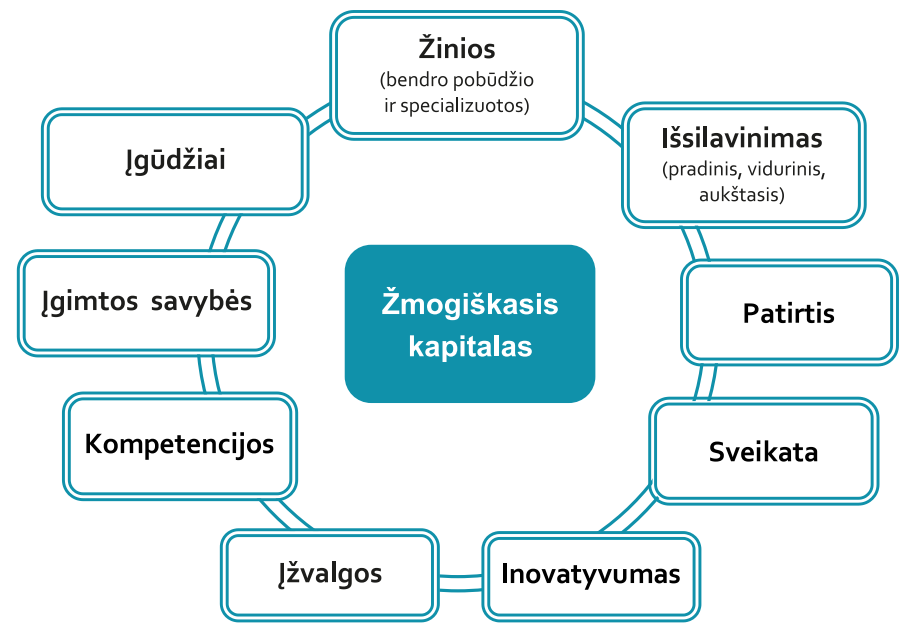

Šaltinis: sudaryta autorių

Remiantis moksliniuose šaltiniuose randamais ịvairiais žmogiškojo kapitalo koncepcijos požiūriais, apibendrinant galima pateikti suformuluotą žmogiškojo kapitalo apibrèžimą: žmogiškasis kapitalas - tai asmens žinios, ł̇gyti igūdžiai, išsilavinimas, igimti sugebejimai, patirtis, nuostatos, elgsena, intelektas, kūrybingumas, verslumas, motyvacija, inovatyvumas, ǰžvalgos, sukaupta patirtis, fizinè, emocinė ir psichinè sveikatos būklè, energija, orientacija aplinkoje, gebant savo žinias ir igūdžius tinkamai ir laiku panaudoti, bei kitos asmens savybès, leidžiančios padidinti individo darbo produktyvumą ir pajamas darbo užmokesčio forma. 
Tačiau pažymètina, kad nors paprastai žmogiškasis kapitalas traktuojamas kaip igūdžių ir tam tikrų charakteristikų, didinančių darbuotojo produktyvumą, visuma, apimanti daug minètų sudedamujų dalių: t. y. išsilavinimą, profesinį tobulejimą, sveikatą, igūdžius, gebejjimus, migravimą ị geresnę darbo vietą ir pan., tačiau išsilavinimas paprastai yra išskiriamas kaip svarbiausias žmogiškojo kapitalo elementas (Goode, 1959; Schultz, 1961; Khilji 2005, Afzal et al., 2012).

\section{Žmogiškojo kapitalo formavimas}

Šiuolaikinèje ekonominèje literatūroje išskirtinio dėmesio sulaukia žmogiškojo kapitalo formavimo problema. Kaip pažymi J. Bagdanavičius (2002), kiekvienam individui būdingi ypatingi žmogiškojo kapitalo formavimo procesai, kurie priklauso nuo individualių sugebejimų specifikos. Tie patys ištekliai, skirti žmogiškojo kapitalo formavimui, skirtingiems individams gali duoti skirtingus žmogiškojo kapitalo dydžius bei rezultatą.

Žmogiškojo kapitalo formavimas igyja skirtingas formas ir pereina ịvairius etapus kartu su žmogaus gyvenimo ciklu (Yamauchi, 2010). Žmogiškojo kapitalo formavimo pagrindas yra naujų žinių ir igūdžių igijimas. Tačiau žinios ir igūdžiai yra ịtvirtinti žmonèse, todèl sudėtinga juos atskirti nuo asmens sveikatos, kuri taip pat turi ịtakos darbo produktyvumui (Strauss ir Thomas,1995). Be to, tarpusavio žmonių sąveika taip pat veikia žinių sklaidą visuomeneje (Romer, 1986, Lucas 1988), todèl visuomenès sudètis (struktūra) yra labai svarbi formuojant žmogiškąji kapitalą.

Žmogiškojo kapitalo formavimą bei jo naudojimą veikia ịvairūs veiksniai. Žmogiškojo kapitalo formavimui ịtakos turinčius veiksnius galima suskirstyti ịvairiai, pavyzdžiui, pagal jų ịtakos rezultatą (teigiamas / neigiamas), ịtakos tipą (tiesioginis / netiesioginis ar ekstensyvus / intensyvus), itakos lygi (makro- / mezo- / makroekonominis / ar individualus). 2 paveiksle pateiktas galimas veiksnių, turinčių ịtakos žmogiškojo kapitalo formavimui, grupavimas.

2 pav. Žmogiškojo kapitalo formavimui įtakos turintys veiksniai

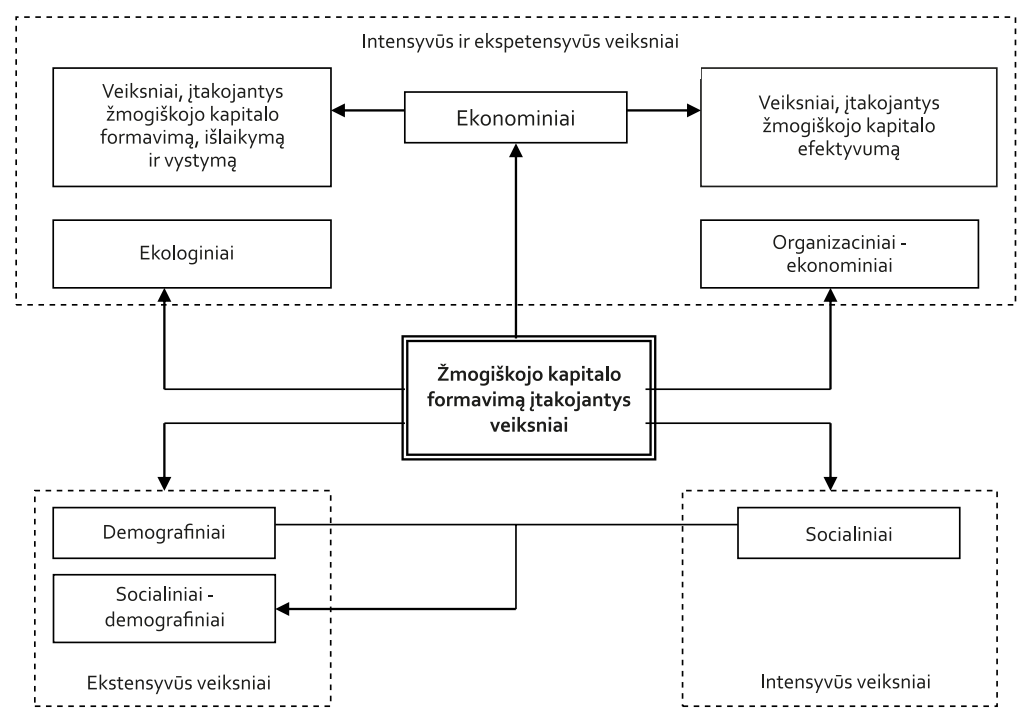

Šaltinis: sudaryta remiantis Verhoglyadova, 2006 
Intensyvūs veiksniai veda link žmogiškojo kapitalo augimo mobilizuojant vidinius sistemos rezervus, t. y. kokybinius parametrus. Kita vertus, ekstensyvūs veiksniai taip pat veikia sistemos kiekybinius parametrus. Tuo pat metu visi veiksniai yra daugiau ar mažiau intensyvūs ir turi įtakos žmogiškojo kapitalo formavimui ir jo naudojimui. Galima įvardinti tris pagrindinius veiksnius, tiesiogiai apibrěžiančius regioninio žmogiškojo kapitalo dydị: ekonominai dydžiai - aktyvių gyventojų skaičius ir jo augimo greitis, išsilavinimo lygio indeksas ir gyventojų sveikatos būklè. Kiti veiksniai veikia daugiausia netiesiogiai. 1 lenteleje pateikiamos žmogiškajj kapitalą formuojančių veiksnių charakteristikos bei ịtakos lygis.

1 lentelè. Žmogiškojo kapitalo formavimui ịtakos turinčių veiksnių charakteristikos

\begin{tabular}{|c|c|c|}
\hline Veiksniai & Apibūdinimas & Itakos lygis \\
\hline Demografiniai & $\begin{array}{l}\text { - Gyventojai } \\
\text { - Gyventojų pasiskirstymas pagal lytị ir amžių } \\
\text { - Gyventojų natūralus augimo tempas } \\
\text { - Vidutinė gyvenimo trukmė }\end{array}$ & $\begin{array}{l}\text { Mezoekonominis ir } \\
\text { makroekonominis }\end{array}$ \\
\hline $\begin{array}{l}\text { Socialiniai de- } \\
\text { mografiniai }\end{array}$ & \begin{tabular}{|l|} 
- Ekonomiškai aktyvių gyventojų dydis \\
- Ekonomiškai aktyvių gyventojų pasiskirstymas pagal pra- \\
monės šakas ir ekonomikos sektorius \\
- Dirbančių ir nedirbančių gyventojų skaičius \\
- Dirbančių ir nedirbančių gyventojų skaičiaus administra- \\
cinis teritorinis pasiskirstymas \\
- Darbingo aktyvaus gyvenimo trukmė
\end{tabular} & $\begin{array}{l}\text { Mezoekonominis ir } \\
\text { makroekonominis }\end{array}$ \\
\hline Socialiniai & $\begin{array}{l}\text { - Gyventojų pagrindinio išsilavinimo ir profesinès kompe- } \\
\text { tencijos lygis } \\
\text { - Sveikatos būklè ir kultūros lygis } \\
\text { - Teritorinis socialinės infrastruktūros išsivystymo lygis } \\
\text { - Migracijos tempai }\end{array}$ & $\begin{array}{l}\text { Individualus, mi- } \\
\text { kroekonominis, } \\
\text { mezo- ekonominis ir } \\
\text { makroekonominis }\end{array}$ \\
\hline \begin{tabular}{|l|} 
Ekonominiai: \\
formavimo, \\
išlaikymo ir vys- \\
tymo veiksniai \\
\end{tabular} & $\begin{array}{l}\text { - Gyventojų realios pajamos } \\
\text { - Gyventojų pasiskirstymas pagal pajamų grupes } \\
\text { - Gyventojų mokumo pajejgumas } \\
\text { - Infliacijos lygis ir ekonomikos stabilumas }\end{array}$ & $\begin{array}{l}\text { Individualus, mi- } \\
\text { kroekonominis, } \\
\text { mezo- ekonominis ir } \\
\text { makroekonominis }\end{array}$ \\
\hline \begin{tabular}{|l|} 
Veiksniai, tu- \\
rintys itakos \\
naudojimo efek- \\
tyvumui
\end{tabular} & $\begin{array}{l}\text { - Darbo paklausos (laisvų darbo vietų) kiekybinès ir koky- } \\
\text { binès charakteristikos } \\
\text { - Techninio ir ekonominio išsivystymo lygis } \\
\text { - Bendra dabartinè ekonominè situacija } \\
\text { - Visų ekonomikos lygių valdymo efektyvumas }\end{array}$ & $\begin{array}{l}\text { Individualus, mi- } \\
\text { kroekonominis, } \\
\text { mezo- ekonominis ir } \\
\text { makroekonominis }\end{array}$ \\
\hline $\begin{array}{l}\text { Organizaciniai- } \\
\text { ekonominiai }\end{array}$ & $\begin{array}{l}\text { - Ekonominio funkcionavimo organizacinis mechanizmas } \\
\text { (kreditų fiskalinis mechanizmas, mokesčių sistema, darbo } \\
\text { stimuliacijos sistema, darbo jègos išsidèstymas teritorijoje) } \\
\text { - Gamybos specializacijos, koncentravimo, bendradarbia- } \\
\text { vimo lygis } \\
\text { - Tarptautiniu ekonominiu ryšiu padètis }\end{array}$ & $\begin{array}{l}\text { Mikroekonominis, } \\
\text { mezo - ekonominis ir } \\
\text { makroekonominis }\end{array}$ \\
\hline Ekologiniai & $\begin{array}{l}\text { - Bendra ekologiné situacija teritorijoje } \\
\text { - Geriamojo vandens ir maisto kokybė } \\
\text { - Gamtinès klimato sąlygos } \\
\text { - Sanitarinès ir higienos darbo sąlygos } \\
\text { - Teritorijos rekreacinè charakteristika }\end{array}$ & $\begin{array}{l}\text { Individualus, mikro- } \\
\text { ekonominis, mezo - } \\
\text { ekonominis ir makro- } \\
\text { ekonominis }\end{array}$ \\
\hline
\end{tabular}

Šaltinis: sudaryta remiantis Verhoglyadova, 2006 
Kaip nurodo F. Yamauchi (2010), asmens žmogiškojo kapitalo formavimas prasideda prieš jam gimstant, tèvams nusprendus susilaukti palikuonio. Vèliau vaiko žmogiškojo kapitalo kaupimo rezultatams ịtakos turi mokykla (Alderman et al., 2000), o nuo jų dar vèliau priklauso ir darbo rinkos rezultatai. Taigi, žmogiškojo kapitalo formavimo procesas vyksta ilgu laikotarpiu. Asmeniui žmogiškojo kapitalo kaupimo nauda pasireiškia paprastai per didesnes darbo pajamas: kvalifikuoti darbuotojai gauna didesnius atlyginimus, yra labiau gerbiami ir patikimi, pasižymi stabiliu ir ilgalaikiu darbu bei didesniu horizontaliuoju ir vertikaliuoju mobilumu (Afzal, 2011).

Žmogiškojo kapitalo kaupimas taip pat yra ir ekonomikos augimo pagrindas. Daugelyje šalių, patyrusių sèkmingą ekonomikos augimą, žmogiškojo kapitalo kaupimas buvo svarbus veiksnys, galèjęs paaiškinti augimą (Hayami ir Godo 2005). Ekonomikoje žmogiškasis ir fizinis kapitalas ilgu laikotarpiu veikia tolesnių investicijų i žmogiškajj ir fizinị kapitalą greitejjimą (Lucas, 1988). Visuotinai sutariama, kad žmogiškojo kapitalo formavimas ir kaupimas yra labai svarbus kiekvienai šaliai, tačiau sukauptas žmogiškojo kapitalo lygis yra skirtingas tiek tarp ịvairių šalių, tiek tarp ịvairių kultūrų (Chani et al., 2012). Kita vertus, turtingos ir išsivysčiusios šalys daugiau investuoja į švietimą, palyginti su skurdesnèmis ar besivystančiomis šalimis, nes turi daugiau finansinių išteklių investuoti ị žmogiškojo kapitalo kaupimą, siekiant gauti daugiau naudos pasauliniu mastu (Heyneman, 1999; Elu, 2000, Oketch 2000). Azijos šalių ekonomikų patirtis rodo, kad žmogiškasis kapitalas yra vienas iš daugelio svarbių veiksnių, galinčių padidinti ekonomikos augimą (World Bank, 1993). Todèl žmogiškojo kapitalo formavimas ir kaupimas bei, žinoma, žmonių ekonominès gerovès plètojimas yra kiekvienos šalies pagrindinis ekonominės politiko suždavinys.

Kaip rodo atliktos mokslinès literatūros analizès rezultatai, ̨̣vairių mokslininkų atlikti tyrimai patvirtina, kad žmogiškojo kapitalo kaupimas (ypatingai per švietimą) suteikia naudą tiek individams, tiek įmonėms (organizacijoms), tiek ir visai visuomenei. Ši nauda gali būti visų pirma ekonominio pobūdžio ir pasireikšti papildomų pajamų, produktyvumo ar ekonominio augimo forma bei plataus spektro neekonominio (nepiniginio) pobūdžio, ịskaitant didesnę socialinę sanglaudą, mažesnị nusikalstamumą, geresnę visuomenès sveikatą ir naujų technologijų bei inovacijų šalies ùkyje diegimą.

\section{Išvados}

Žmogiškojo kapitalo teorijos ištakos siekia XVII-XIX a. Pirmuoju ekonomistu, pripažinusiu žmogaus ekonominę vertę, yra laikomas Seras W. Petty, pats žinomiausias Ekonomikos politinès aritmetikos mokyklos ịkūrẻjas ir taikomosios ekonometrikos pirmtakas, kurio studijos buvo sutelktos ị žmogiškojo kapitalo piniginị ịvertinimą ir emigracijos itaką ekonomikai.

XIX a. pabaigoje - XX a. pradžioje susiformavo dvi ekonominės minties kryptys, analizuojančios sąvoką „Žmogiškasis kapitalas“. Vienos krypties šalininkai (A. Smith, F. List, J. B. Say, J. St. Mill, W. Rosher, W. Bagehot, N. Senior, H. Sidwick, F. List, G. Z. Walsh ir kt.) asmens igūdžius ir gebejjimus buvo ịtraukę ì pagrindinị kapitalą, laikydamiesi nuomonès, kad igūdžiai ir gebejjimai yra igyjami patiriant tam tikras išlaidas, kurios paprastai didina asmens / darbuotojo produktyvumą. Tačiau jie konkrečiai ir aiškiai neįvardijo žmonių kaip kapitalo ir laikèsi nuostatos, kad kapitalas priklauso nuo žmogaus savybių ir gebejjimų. Kitos krypties šalininkai (L.Valras, G. M. Clark, H. D. McLeod, T. Witshtane, W. Farr, I. Fisher, 
N. W. Senior, H. D. McCleod, J. H. von Thünen, J. R. McCulloch, A. Marshal ir kt.) žmogų vertino kaip kapitalą. Tačiau nors jie žmones ar jų ígytus igūdžius ir gebejjimus įtraukè ị savo kapitalo koncepciją ir investavimą i žmones mate kaip produktyvumo didinimo galimybę, jie nenaudojo šios koncepcijos jokiam konkrečiam tikslui ir nẻ nebandè įvertinti žmogiškojo kapitalo kiekybiniu požiūriu.

Šiuolaikine žmogiškojo kapitalo teorija susiformavo 1960-1970 metais, pasirodžius T. W. Schultzo, pripažinto šios idejos autoriumi, G. S. Beckerio ir J. Mincerio darbams. Šiuo metu yra visuotinai pripažįstama žmogiškojo kapitalo reikšmė ir jo reikšminga ịtaka tiek individo, tiek visuomenès požiūriu. Visuotinai sutariama, kad žmonių žinių ir igūdžių ịvairovė bei skirtingi jų lygiai yra potencialus ekonomikos augimo ir gerovès kūrimo šaltinis.

Atlikti tyrimai parodè, kad žmogiškojo kapitalo sąvoka yra plati ir traktuojama labai ¿̇vairiai. Autoriai pabrèžia vieną ar kitą žmogiškojo kapitalo aspektą, atsižvelgdami ị jų konkrečius tyrimų tikslus, keliamus uždavinius ir kontekstą.

Apibendrinus apibrěžimų ívairovę galima skirti šiuos pagrindinius bendrus žmogiškojo kapitalo turinio elementus - tai žinios, išsilavinimas, patirtis, sveikata, kompetencija, asmeninès / igimtos savybès ir igūdžiai.

Atlikta mokslinès literatūros analizė žmogiškojo kapitalo tema šio straipsnio autorèms leido suformuluoti vieną žmogiškojo kapitalo apibrèžimą: žmogiškasis kapitalas - tai asmens žinios, igyti igūdžiai, išsilavinimas, tgimti sugebejjimai, patirtis, nuostatos, elgsena, intelektas, kūrybingumas, verslumas, motyvacija, inovatyvumas, ǐžvalgos, patirtis, fizinė, emocinė ir psichinè sveikatos būklè, energija, orientacija aplinkoje, gebant savo žinias ir igūdžius tinkamai ir laiku panaudoti, bei kitos asmens savybès, leidžiančios padidinti individo darbo produktyvumą ir pajamas darbo užmokesčio forma.

Šiuolaikinèje ekonomineje literatūroje išskirtinio dėmesio sulaukia žmogiškojo kapitalo formavimo problema. Kiekvienam individui būdingi ypatingi žmogiškojo kapitalo formavimo procesai, kurie priklauso nuo individualių sugebejjimų specifikos, nes tie patys ištekliai, skirti žmogiškojo kapitalo formavimui, skirtingiems individams gali duoti skirtingus žmogiškojo kapitalo dydžius bei rezultatą.

Atsižvelgiant ị tai, kad žmogiškojo kapitalo formavimą bei jo naudojimą veikia ịvairūs veiksniai, žmogiškojo kapitalo formavimui ittakos turinčius veiksnius galima skirstyti ¿̇vairiai: pagal jų ịtakos rezultatą (teigiamas / neigiamas), įtakos tipą (tiesioginis / netiesioginis ar ekstensyvus / intensyvus), ittakos lygi (makro- / mezo- / makroekonominis / ar individualus). Bendruoju atveju veiksnius, turinčius įtakos žmogiškojo kapitalo formavimui, galima sugrupuoti ị 6 grupes: (1) demografinius (pvz., gyventojų pasiskirstymas pagal lytị ir amžių); (2) socialinius demografinius (pvz., dirbančių ir nedirbančių gyventojų skaičius); (3) socialinius (pvz., sveikatos būklè, kultūros lygis, migracijos tempai); (4) ekonominius, išskiriant juos ị veiksnius, veikiančius žmogiškojo kapitalo formavimą, išlaikymą ir vystymą (pvz., gyventojų pasiskirstymas pagal pajamų grupes) ir veiksnius, turinčius ịtakos žmogiškojo kapitalo efektyvumui (pvz., bendra ekonominè padètis); (5) organizacinius-ekonominius (pvz., gamybos specializacijos, koncentravimo lygis) ir (6) ekologinius veiksnius (pvz., gamtinès klimato, sanitarinès sąlygos). 


\section{Literatūra}

Abeltina, A. (2008). The role of human capital in regional development. 5th International Scientific Conference Business and Management'2008, (483-489), Vilnius Gediminas Technical University: Technika.

Afzal, M. (2011). Microeconometric analysis of private returns to education and determinants of earnings. Pakistan Economic and Social Review, 49(1): 39-68.

Afzal, M., Malik, M. E., Begum, I., Sarwar, K., and Fatima, H. (2012). Relationship among Education, Poverty and Economic Growth in Pakistan: An Econometric Analysis. Journal of Elementary Education, 22 (1): 23-45.

Aghion, Ph., and Howitt, P. (1992). A Model of Growth Through Creative Destruction. Econometrica, 60(2): 323-351.

Akbari, N., Moayedfar, R., and Jouzaryan, F. (2012). The study and analysis of short run and long run effects of human capital on the economic growth in Iran. Economics and Finance Review, 1(11): 1-9.

Alderman, H., Behrman J., Lavy V., and Menon, R. (2000). Child health and school enrollment: A longitudinal analysis. Journal of Human Resources, 36 (1): 185-205.

Bagdanavičius, J. (2002). Žmogiškasis kapitalas. Vilnius. Žiūrèta 2012 m. kovo 15d. Prieiga per internetą: http://www.vpu.lt/bibl/elvpu/29966.pdf.

Barney, J. (1991). Firm resources and sustained competitive advantage. Journal of Management, 17(1): 99-120.

Barney, J. (2011). Gaining and Sustaining Competitive Advantage (4th Edition), Prentice Hall.

Becker, G. S. (1962). Investment in human capital: a theoretical analysis. Journal of Political Economy, 70(5.2): 9-49.

Becker, G. S. (1964). Human Capital: A Theoretical and Empirical Analysis. New York: Columbia University Press for the National Bureau of Economic Analysis.

Becker, G. S. (1975). Human capital, 2nd ed. Chicago: University of Chicago, Press.

Becker, G. S. (1992). The economic way of looking at life//Nobel lecture.December 9, USA. Žiūrèta 2012 m. balandžio 1d. Prieiga per internetą: http://home.uchicago.edu/gbecker/Nobel/nobellecture.pdf

Becker, G. S. (1993a). Human Capital: A Theoretical And Empirical Analysis With Special Reference To Education, 3rd Ed. Chicago: The University of Chicago Press.

Becker, G. S. (1993b). Nobel lecture: The economic way of looking at behavior. Journal of Political Economy, 101 (3):385-409.

Bloom, E. D., and Siow, A. (1993). Some reflections on Jacob Mincer in 'Essays in Honor of Jacob Mincer. Journal of labor economics, 11(1) Part 1: v-vii.

Blundell, R., Dearden, L., Meghir, C., and Sianesi, B. (1999). Human capital investment: the returns from education and training to the individual, the firm and the economy. Fiscal studines, 20(1): $1-23$.

Bontis, N. (2001). Assessing knowledge assets: A review of the models used to measure intellectual capital. International Journal of Management Reviews, 3, 41-61.

Bowles, S., and Gintis, H. (2001). Schooling in Capitalist America. Žiūrèta 2012 m. spalo 21d. Prieiga per internetą: http://www.umass.edu/preferen/gintis/soced.pdf.

Carnoy, M. (1995). Education and Labor Markets, in M. Camoy (Ed.) International Encyclopedia of Education. (312-315). Tarrytown, NY: Elsevier.

Chani, M. I., Hassan, M. U., and Shahid, M. (2012). Human capital formation and economic development in Pakistan: an empirical analysis. MPRA Paper No. 38925. Žiūrèta 2012 m. gruodžio 15 d. Prieiga per internetą: http://mpra.ub.uni-muenchen.de/38925/1/MPRA_paper_38925.pdf.

Chlivickas, E., ir Papšienė, P. (2009a). Investicijų ị žmogiškąji kapitalą svarba visuomenei. Verslas, studijos ir aš. Trečiosios dèstytojų, studentų ir socialinių partnerių tarptautinès mokslinès-praktinès konferencijos, vykusios 2009 m. vasario 27 d., tezès (28-30). Šiauliai: Šiaulių kolegija.

Chlivickas, E., ir Papšienè, P. (2009b). Investicijos ị žmogiškąji kapitalą: sẻkmės strategija. Viešasis administravimas $=$ Public administration. 1(21): 39-44. Vilnius: Lietuvos viešojo administravimo lavinimo institucijų asociacija. 
Coleman, J. S. (1993). The impact of Gary Becker's work on sociology. Acta Sociologija, 36: 169-178.

Corona Alcantar, J. M. (2006). Human capital formation: The role of science and technology policy. A case study in the Mexican biotechnology sector, PhD thesis, PREST - Manchester Business School. The University of Manchester. UK.

Dae-Bong, K. (2009). Human capital and its measurement. The 3rd OECD World Forum on "Statistics, Knowledge and Policy" Charting Progress, Building Visions, Improving LifeBusan, Korea.

Davenport, T. O. (1999). Human capital. Management Review, 88 (11): 37-43.

Davidsson, P., and Honig, B. (2003). The role of social and human capital among nascent entrepreneurs. Journal of Business Venturing, 18 (3): 301-331.

De la Fuente, A., and Ciccone, A. (2002). Human capital in a global and knowledge-based economy, Final report. UFAE and IAE Working Papers 562.03, Unitat de Fonaments de l'Anàlisi Econòmica (UAB) and Institut d'Anàlisi Econòmica (CSIC).

Dess, G. G., and Picken, J. C. (1999). Beyond Productivity: How leading companies achieve superior performance by leveraging their human capital. New York : AMACOM.

Дятлов, С. А. (1994). Основы теории человеческого капитала. Издательство Санкт-Петербургского Государственного Университета Экономики И Финансов.

Dzinkowski, R. (2000). The measurement and management of intellectual capital: an introduction. Management Accounting (UK), 78(2), February, 32-36.

Edvinsson, L., and Sullivan, P. (1996). Developing a model for managing intellectual capital, European Management Journal, 14(4): 356-364.

Edvinsson, L., and Malone, M. (1999). Intellectual Capital. New York: HarperCollins Publishing, Inc.

Ekonomikos terminų žodynas. Žiūrèta 2013 m. rugpjūčio 4 d. Prieiga per internetą: http://www.ekonomika.lt/ekonomikos-terminu-zodynas/darbas\#ixzz2hESMvzB6.

Elu, J. (2000). Human development in sub-Saharan Africa: Analysis and prospects for the future. Journal of Third World Studies, 17(2): 53-71.

Folloni, G., and Vittadini, G. (2010). Human capital measurement: a survey. Journal of Economic Surveys, 24(2): 248-279.

Frank, R. H., and Bernanke, B. S. (2007). Principles of Microeconomics (3rd ed.). New York: McGrawHill/Irwin.

Goode, R. B. (1959). Adding to the stock of physical and human capital. American Economic Review, 49(2): 147-155.

Grossman, G. M., and Helpman, E. (1991). Innovation and Growth in the Global Economy. Cambridge, MA, MIT Press.

Hayami, Y., and Godo, Y. (2005). Development economics: From the poverty to the wealth of nations. Oxford: Oxford University Press.

Hartog, J. (1999). Behind the Veil of Human Capital. Organisation for Economic Cooperation and Development. The OECD Observer, January, No 215.

Heyneman, P. (1999). Education in sub-Saharan Africa: Serious problems, significant opportunities. Report presented at the African Summit Conference, Houston, TX. April 24.

Hofflander, A. E. (1966). The human life value: an historical perspective. Journal of Risk and Insurance, 33(3): 381-391.

Yamauchi, F. (2010). Human Capital Formation: history, Expectations, and Challenges in South Africa. International Food Policy Research Institute.

Jacob Mincer's Biography. Žiūrèta 2012 m. balandžio 19d. Prieiga per internetą: http://www.allvoices. com/people/Jacob_Mincer.

Kagochi, J. M., and Jolly, C. M. (2010). R\&D Investments, human capital, and the competitiveness of selected U.S. agricultural export commodities. International Journal of Applied Economics, 7(1): $58-77$.

Keeley, B. (2007). Human capital: how what you know shapes your life. OECD. Paris, France.

Khilji, B. A. (2005). Education as a factor of human capital formation in Pakistan (1951-1998): Review. Journal of Agriculture and Social Sciences, 1(2): 180-186.

Kiker, B. F. (1966). The historical roots of the concept of human capital. Journal of Political Economy, 74(5): 481-499. 
King, R. G., and Rebelo, S. (1990). Public policy and economic growth: developping neoclassical implications. Journal of Political Economy, 98(5, Part 2, Supplement): S126-S149.

Knight, D. J. (1999). Performance measures for increasing intellectual capital. Strategy \& Leadership, 27(2): 22-27.

Корицкий, А. В. (2007). Кладовые капитала. Истоки и основные положения теории человеческого капитала. Креативная экономика,(5): 3-10.

Kuliešis, G., Pareigienė, L., ir Naus, I. (2012). Kaimo žmogiškojo kapitalo raida. Mokslo studija. Vilnius: Lietuvos agrarinès ekonomikos institutas.

Laroche, M., Mérette, M., and Ruggeri, G. C. (1999). On the Concept and Dimensions of Human Capital in a Knowledge-Based Economy Context. Canadian Public Policy, XXV(1): 87-100.

Le, T., Gibson, J., and Oxley, L. (2005). Measures of Human Capital: A Review of the Literature. Working paper 5/10. New Zealand Treasury.

Legenzova, R., ir Ščetko, S. (2001). Intelektualaus kapitalo koncepcija Lietuvos finansų rinkos kontekste. Organizaciju vadyba: sisteminiai tyrimai, 18: 73-85.

Lepak, D. P., and Snell, S. A. (1999). Thc human resource architecture: toward a theory of human capital allocation and development, academy of management. The Academy of Management Review, 24(1): 31-48.

Lipsey, R. G, Courant, P. N., and Ragan, C. T. S. (1999). Economics. (12th ed.) Addison-Wesley Longman.

Lynn, B. E. (2000). Intellectual capital: Unearthing hidden value by managing intellectual assets, Ivey Business Journal, 648(3) January/February: 48-52.

Lynn, M. (2002). The ROI of human capital. HR Professional, 19(4): 34-45.

Lovaglio, P. G., and Folloni, G. (2011). The estimation of Human Capital in structural models with flexible specification. AlmaLaurea working papers, No. 11.

Lucas, R. E. (1988). On the mechanics of economic development. Journal of Monetary Economics, 22(1): 3-42.

Mankiw, N. G., Romer, D., and Weil, D. N. (1992). A Contribution to the empirics of economic growth. Quarterly Journal of Economics, 107: 407-37.

Marthur, V. (1999). Human capital-based strategy for regional economic development. Economic Development Quarterly, 13(3): 203-216.

Matiušaitytè, R., ir Šarkiūnaitė, I. (2003). Žmogiškojo kapitalo reikšmė ekonomikoje ir vadyboje. Tiltai: humanitariniai ir socialiniai mokslai, priedas Nr. 13, t. 1.

Mincer, J. (1962). Labor Force Participation of Married Womenin H. Gregg Lewis, ed., Aspects of Labor Economics. Universities-National Bureau. Princeton University Press.

Mincer, J. (1958). Investment in human capital and personal income distribution. Journal of Political Economy, 66(4): 281-302.

Mincer, J. (1974). Schooling, Experience and Earnings. New York: National Bureau of Economic Research.

Mincer, J. (1981). Human capital and economic growth. NBR working paper.

Nafukho, F. M., Hairston, N., and Brooks, K. (2004). Human capital theory: implications for human resource development. Human Resource Development International, 7(4): 545-551. Žiūrèta 2012 m. spalio 21d. Prieiga per internetą: http://dx.doi.org/10.1080/1367886042000299843.

Nureev, R. M. (2010). Human Capital and Its Development in Present-Day Russia. Russian Education \& Society, 52(3): 3-29. Žiūrèta 2013 m. gegužès 4 d. Prieiga per internetą: http://rustem-nureev. $\mathrm{ru} / \mathrm{wp}$-content/uploads/2011/03/389.pdf.

OECD (2001). The well being of nations: the role of human and social capital. Paris, France. Žiūrèta 2013 m. rugsèjo 1d. Prieiga per internetą: www.oecd.org/dataoecd/36/40/33703702.pdf.

Oketch, M. O. (2000). Costing and financing higher education for development in Africa: Kenya's case. International Education Electronic Journal, 3(4): 1-100.

Onyemunwa, S., and Achime, H. (2000). The Financial Rewards of Investment in Education, Health and Human Capital. Nigeria Journal of Administrative Science, 5(1): 43-52.

Parkin, M. (2000). Macroeconomics. (5th. Edition), Addison-Wesley Publishing Inc.

Pass, Ch., Lowes, B., and Davies, L. (1997). Ekonomikos terminu žodynas. Vilnius: Baltijos biznis. 
Press Release (1992). The Sveriges Riksbank Prize in Economic Sciences in Memory of Alfred Nobel. Gary S.Becker. (1992 October 13). Žiūrèta 2012 m. balandžio 1 d. Prieiga per internetą: http:// www.nobelprize.org/nobel_prizes/economics/laureates/1992/press.html.

Psacharopoulos, G., and Woodhall, M. (1985). Education for development: an analysis of investment choices. New York: Oxford University Press.

Rebelo, S. (1991). Long-Run Policy Analysis and Long-Run Growth, Journal of Political Economy, 99(3): 500-521.

Romer, P. M. (1986). Increasing returns and the long-run growth, Journal of Political Economy, 94 (5): 1002-1037.

Romer, P. M. (1989). Human capital and growth: theory and evidence. NBER Working Papers 3173, National Bureau of Economic Research, Inc.

Romer, P. M. (1990). Endogenous technological change. Journal of Political Economy, 95 (Part 2, Supplement): S71-S102.

Roos, J., Roos, G., Dragonetti, N., and Edvinsson, L. (1998). Intellectual Capital: Navigating in the New Business Landscape. New York: New York University Press.

Rosen, H. S. (1999). Public finance. New York: McGraw-Hill.

Schultz, T. W. (1962). Reflections on Investment in Man. Journal of Political Economy, 70: 1-8. University of Chicago Press.

Schultz, T. W. (1961). Investment in human capital. American Economic Rewiew, 51(1): 1-17 (reprinted 2004).

Schultz, T. W. (1998). Investavimas į žmones. Gyventojų kokybès ekonomika. Vilnius: Eugrimas.

Siddiqui, S. A. (1996). Factors of production and factor returns under political economy of Islam. Journal of King Abdulaziz University. Islamic Economics, 8(1): 3-28.

Smith, A. (1776/2009). An inquiry into the nature and causes of the wealth of nations. A digireads.com book. Žiūrèta 2012 m. rugsèjo 24 d. Prieiga per internetą: http://books.google.lt/books?id=rBiqT86BGQEC\&printsec $=$ frontcover\# $\mathrm{v}=$ onepage $\& \mathrm{q} \& \mathrm{f}=$ false.

Stewart, T. (1997). Intellectual Capital: The New Wealth Of Organizations. Nicholas Brealey Publishing, Business Digest, New York.

Strauss, J., and Thomas, D. (1995). Human resources: Empirical modeling of household and family decisions. In Handbook of development economics, Vol. 3, ed. J. R. Behrman and T. N. Srinivasan. Amsterdam, Netherlands: Elsevier.

Sullivan, A., and Sheffrin, S. M. (2003). Economic Principles in Action. Upper Saddle River, New Jersey: Pearson Prentice Hall.

Sweetland, S. R. (1996). Human Capital Theory: Foundation of a Field of Inquiry. Review of Education Research, 66: 341-359.

Šileika, A., ir Tamašauskienè, Z. (2003). Investicijos ị žmogiškąjị kapitalą ir jų efektyvumas. Ekonomika, 64: 146-157.

Turunen, O. T. (2007). Immaterial capital. Ideas of human and social capital in the older historical. School of German political economy. Progradu thesis in history. University of Jyväskylä.

Van Buren, M. E. (1999). A yardstick for knowledge management.Training \& Development, 53: 71-8.

Verhoglyadova, N. I. (2006). Definition and content interpretation of human capital. Annals. Computer Science Series, 4(1): 249-259. Mirton Publishing House, Timisoara.

Weisbrod, B. A. (1966). Investing in Human Capital. The Journal of Human Resources, 1(1), Summer: 5-21. Reprinted 2011.Published by: University of Wisconsin Press.

Woodhall, M. (1995). Human Capital Concepts, in M. Carnoy (Ed.). International Encyclopedia of Economics of Education. (24-28). London: Pergamon.

World Bank (1993). The East Asian miracle: Economic growth and public policy. Washington, D.C. 


\title{
HUMAN CAPITAL CONCEPTUALIZATION: DEVELOPMENT AND CONCEPT FORMATION
}

\author{
Simona POTELIENĖ \\ Zita TAMAŠAUSKIENĖ \\ Šiauliai University, Lithuania
}

Summary. The concept of human capital is an old one. Perhaps the first to try to define and measure what now is called human capital was Sir William Petty (1623-1687). The most prominent founder of the Political Arithmetic School of Economics and a forerunner of applied econometrics, Petty was concerned with the main national socioeconomic and political roles of human capital. He believed that labour was the "father of wealth" and that a measure of its value should be included in the estimation of national wealth. Petty's thesis was that factors other than land and population were important in determining the wealth of a nation. Later, it was studied in works of Ph. Cantillon, J.H. von Thünen, A. Smith, A. Marshall, J.St. Mill, W. Farr, K. Marks, I. Fisher and other scholars.

At the end of the 19th and beginning of 20th centuries, there were formed two directions of economic thought, which discussed the definition of the "human capital" term. The representative of one direction scholars (A. Smith, F. List, J.B. Say, J.St. Mill, W. Rosher, W. Bagehot, N. Senior, H. Sidwick, F. List, G.Z. Walsh and others) considered that the capital is presented as inherited and possessed by man qualities and abilities, but they did not explicitly include human beings as capital. The representative of another direction scholars (L. Valras, G.M. Clark, H.D. McLeod, T. Witshtane, W. Farr, I. Fisher, N.W. Senior, H.D. McCleod, J.H. von Thünen, J.R. McCulloch, A. Marshal and others) defined the man himself as capital. Though they included human beings or their acquired skills and abilities in their concept of capital and saw investment in people as a means of increasing productivity, they did not use the concept for any specific purpose, nor did they try to estimate the stock of human resources in a quantitative sense.

However, as a special field of economic analysis, the theory of human capital was formed only at the frontier of the 60s - 70s in the 20th century, when J. Mincer (1958), R.B. Goode (1959), T.W. Schultz (1961) and G.S. Becker $(1962,1964,1975)$ gave a different point of view regarding the concept and formation of human capital.

The results of the investigation have shown that human capital is a broad term and is treated very differently. Various authors emphasize one or another aspect of human capital, taking into account their specific research goals, challenges and context. Despite the proliferation of human capital definitions in the literature, a number of key elements seem to be common, encompassing knowledge, education, experience, health, competence, trained skills and endowed abilities.

Given the fact that numerous factors influence forming and exploiting human capital, these factors can be classified according to various scientific descriptors. These classifying descriptors include the following: a result of influence (positive/negative); a type of influence (direct and indirect); a type of influence in the process of renewing (intensive or extensive); a level of influence (macro/mezzo/microeconomic/individual). In general, the factors that influence human capital formation can be grouped into 6 groups: (1) demographic (e.g., sex-age structure of population); (2) socio-demographic (e.g., the number of employed and unemployed population); (3) social (e.g., state of health and the level of culture, internal migration of the population); (4) economic, which is classified into factors of forming, supporting and developing (e.g., income devision according to the population groups) and factors, influencing on use efficiency (e.g., the general current economic situation); (5) organization-economic (e.g., the level of specialization, concentration and cooperation of production); and finally, (6) ecological (e.g., nature-climatic, sanitary-hygienic working conditions).

Keywords: human capital, historical development of human capital economic thought, human capital formalion. 